African Crop Science Journal by African Crop Science Society is licensed under a Creative Commons Attribution 3.0 Uganda License. Based on a work at www.ajol.info/ and www.bioline.org.br/cs DOI: http://dx.doi.org/10.4314/acsj.v24i2.5

\title{
EFFECT OF FARMING PRACTICES AND FARM HISTORY ON INCIDENCE OF COCONUT LETHAL YELLOWING IN MOZAMBIQUE
}

\author{
J. BILA ${ }^{1,2}$, I. PERSSON ${ }^{3}$, N. HÖGBERG ${ }^{1}$, A. MONDJANA ${ }^{2}$, L. MANUEL ${ }^{2}$, E. TOSTÃO², \\ N. JOHANSSON ${ }^{3}$, J. SÖDERLIND ${ }^{3}$ and L. SANTOS ${ }^{2}$ \\ ${ }^{1}$ Department of Forest Mycology and Plant Pathology, Swedish University of Agricultural Sciences, \\ Uppsala, Sweden \\ ${ }^{2}$ Faculdade de Agronomia e Engenharia Florestal, Universidade Eduardo Mondlane, Maputo, Mozambique \\ ${ }^{3}$ Department of Statistics, Uppsala University, Uppsala, Sweden \\ Corresponding author: jbilay@gmail.com
}

(Received 29 November, 2015; accepted 2 May, 2016)

\begin{abstract}
Management of coconut (Cocos nucifera) lethal yellowing disease (CLYD), which has killed about eight million coconut trees in Mozambique, has proved challenging. The objective of this study was to investigate the impact of farming practices and related history, on the CLYD incidence in Mozambique. The methodology included a socioeconomic questionnaire to the households and direct observations on the palm farms. The collected data were analysed using logistic regression. Five out of 11 explanatory variables tested, namely farm age, availability of other palm species on the coconut farm, type of coconut varieties grown, root cut practices, and intercropping had a significant $(\mathrm{P}<0.05)$ effect on CLYD incidence. Coconut farms $<10$ years had higher odds of higher disease incidence compared to the farms between 10 to 40 years old. The presence of other palm species in the coconut farms had two times higher odds of having higher disease incidence levels compared to farms without other palm species. Tall coconut varieties were likely to be more tolerant to CLYD compared to dwarf varieties. Coconut farms with some kind of intercropping had two times higher odds of having higher disease incidence levels compared to pure stands. The practice of cutting coconut roots had three times higher odds of having high disease incidence levels compared to non-practicing farms. Farm age, availability of other palm species on the coconut farm, type of coconut varieties grown, root cut practices and intercropping need to be considered for integrated CLYD management.
\end{abstract}

Key Words: Cocos nucifera, inter cropping, logistic regression

\section{RÉSUMÉ}

La lutte contre la maladie de jaunisse létale (CLYD) du cocotier (Cocos nucifera), qui a décimé près de huit millions de cocotiers au Mozanbique, n'est pas aisée. L'objectif de cette étude était d'évaluer les impacts des pratiques culturales et leur histoire, sur le l'incidence de CLYD au Mozambique. Une enquête socioé-conomique a été administrée aux ménages et des observations directes dans les champs de cocotiers ont été réalisées. Les données collectées ont été analysées par régression logistique. Cinq des onze variables explicatives, à savoir l'âge de la plantation, la presence ou non d'autres espèces de palmiers sur la plantation, le variété de cocotiers plantés, la pratique d'élagage racinaire et la pratique d'association des cultures avaient des effets significatifs $(\mathrm{P}<0.05)$ sur l'incidence de CLYD. Les plantations vieilles de plus de 10 ans présentaient plus de signes de l'incidence de la maladie que les plantations plus vieilles entre 10 et 40 ans. La présence d'autres espèces de palmiers dans la cocoteraie causaient deux fois plus de signes d'incidence de la maladie, comparée aux cocoteraies ne comportant pas d'autres espèces de palmiers. Les variétés de grands cocotiers ont tendance à mieux tolérer le CLYD, 
comparé aux variétés courtes. Les cocoteraies avec association d'autres cultures présentaient deux fois plus de signes de maladies que les cocoteraies simples. La pratique d'élagage racinaire présentait trois fois plus de signe d'incidence de la maladie. Au total, l'âge, la presence ou non d'autres espèces de palmiers, la variété de cocotiers produite, les pratique d'élagage racinaire, et l'association d'autres cultures avec les cocotiers sont à considerer dans pour une lutte intégrée contre CLYD.

Mots Clés: Cocos nucifera, association des cultures, régression logistique

\section{INTRODUCTION}

The coconut palm (Cocos nucifera) is a major cash crop in the coastal regions of Mozambique, and contributes greatly to, income and food security of millions of rural inhabitants. Outbreaks of coconut lethal yellowing disease (CLYD), caused by specialised phytoplasma bacteria, have killed about eight million coconut trees, threatening the industry and the livelihood of over three million people in Mozambique. Phytoplasmas are phloem limited and are transmitted by insect vectors, sucking phloem sap from sieve tubes (Garnier et al., 2001; Weintraub and Beanland, 2006).

For control of phytoplasmas diseases, the primary concern is often prevention rather than treatment. Management includes control of the insect vectors and alternative plant hosts, destroying symptomatic plants and avoiding planting susceptible crops (Lee et al., 2000). In Mozambique, the most common CLYD management strategy is cutting and burning of symptomatic coconut trees, suspected to be infected.

The Mozambique giant green tall variety is still considered to be tolerant, since it survives relatively longer against infection with CLYD, compared to other varieties. Therefore, this variety is widely used to replace dead coconut palms in Mozambique. The recurrence of CLYD disease in replanted devastated coconut farms, coupled with the isolation of lethal yellowing-type phytoplasmas in grass species (Brown et al., 2008; Nejat et al., 2009), support the idea that other factors such as farming practices could have an impact on CLYD incidence. Furthermore, lethal yellowing disease does not kill all susceptible palms in one year; losses usually continue to occur over time for as long as the disease remains active at a particular site (Broshat et al., 2002).
Other studies have reported that cultural control and integrated pest management (IPM) can be achieved by manipulating the habitats occupied by insects vectoring the diseases (Howard and Oropeza, 1998; Caudwell, 2000; Agrios, 2005; Weintraub and Beanland, 2006). In addition, some legumes when used as cover crops provide poor breeding sites and/or do not support development of eggs or other immature stages of some insect pests. For example, larval development of Haplaxius crudus (previously known as Myndus crudus), the vector of lethal yellowing (LY) phytoplasmas in the Caribbean (Brown et al., 2006), is not supported by the legume cover crop, Pueraria phaseoloides (Gitau, 2009). The intensity of CLYD in Mozambique varies significantly among and within the affected areas, which is inconsistent with the largely similar agro-ecological conditions in these areas (Bila et al., 2014). Thus, it is crucial to elucidate both the biology of the Mozambican phytoplasmas including the potential insect vector as well as the impact of agricultural practices. The objective of this study was to investigate the impact of farming practices and related history on the CLYD incidence in Mozambique.

\section{MATERIALS AND METHODS}

Field work. The study was conducted in the Zambezia province (Quelimane city, Inhassunge, Maganja da Costa, Namacurra, Pebane and Nicoadala) and in Nampula province (Moma and Angoche) in Mozambique. It consisted of two main activities (a) a socioeconomic survey involving households (Hhs) to capture information on farming systems, coconut production and household perception of the symptoms and control of CLYD; and (b) direct observations on the palm farms to estimate the incidence and severity of CLYD. Both approaches were conducted simultaneously at 
each household, randomly selected from the target population. The direct observations included a census of the coconut trees of the plantations (live, standing, dead and cut down due to CLYD, showing CLYD symptoms) and recording of additional farming systems data. The target population consisted of all Hhs currently or in a recent past involved in coconut production.

Data from the National Institute of Statistics in Mozambique for the 2007 population census were used to get a list of the sampling population. The final sample population contained 235 enumeration areas (EA), with 26,554 Hhs. Enumeration area was considered as the basic sampling unit that divides the country into statistically homogeneous areas, corresponding to the division in a territory within a village. Random sampling was considered the most appropriate since it would give better chances of capturing information from households in different levels of CLYD infection. Random sampling was performed in two steps; first a selection from the different enumeration areas, and second to select households within the selected EA. A sample of 50 EA and 10 households from each EA was drawn, summing up to a total of 500 observations. The dataset contained 533 different coconut farms, since a household could own more than one farm. The field work was carried out during October and November 2012.

Variables for the statistical models. The dependent variable (disease incidence) was considered as the ordered categorical variable with three levels, denoting (a) disease incidence ranging from $0-5 \%$ of infected trees, (b) disease incidence between 5 and $40 \%$, and (c) more than $40 \%$ of disease incidence. The model included the following variables, namely, farm age (age) was a variable for the age of the coconut farm consisting of three categories. The first category denoted less than 10 years (coded as 1); while the second category denoted an age between 10 to 40 years (coded as 2), which is used as the reference group. The third category denotes more than 40 years (coded as 3 ). Other palm species (pspecies) was a variable describing if there were any other palm species present on the farm. The alternatives were Yes (coded as 1) and No (coded as 0 ).

Planting layout (layout), describing how the palm trees were planted, was a binary variable that denoted if the palm trees were planted in a zig-zag pattern (coded as 1), or if the palm trees stood in lines (coded as 2). The level of weed (weed) was a variable consisting of three categories. A clean farm without any weed, which was referred to as the reference group (coded as 1).

The second category denoted if there was creeping and/or tall grass on the farm (coded as 2 ), and the third category denoted if there was a higher degree of weed including woody plants (coded as 3). Coconut variety (variety) was a variable which described the variety type on the farm, consisting of three categories. The variety could be dwarf (coded as 1), tall (coded as 2), which was the reference group; or a hybrid between dwarf and tall (coded as 3). Removing mature leaves (prune) was a variable describing if farmers cut the mature leaves for other purposes such as fencing or house roofs. The alternatives were Yes (coded as 1) or No (coded as 0$)$.

Holes in stem for climbing (climbing) was a variable describing if farmers dug the stem to make holes for climbing purposes. The alternatives were Yes (coded as 1) or No (coded as 0 ). Inflorescence cut was a variable describing if farmers cut fresh inflorescence for local wine "sura" production purposes. The alternatives were Yes (coded as 1) or No (coded as 0). Root cut (root) was a variable describing if farmers cut roots for other purposes such as medicinal. The alternatives were Yes (coded as 1) or No (coded as 0 ).

Type of soil (soil) was a variable which described the soil on the farm, consisting of three categories. The soil could consist of sand (coded as 1), between sand and soft clay (coded as 2), which is the reference group, or soft clay (coded as 3). Intercropping on the farm (intercropping) was a variable denoting if the farmer cultivated other crops, than the coconut. The alternatives were Yes (coded as 1$)$ or No (coded as 0$)$. 
Data analysis. Data analysis was done using SAS 9.4 Software (SAS Institute Inc. copyright $\odot 2013$, Cary, NC 27513, USA). Based on our hypothesis and study design data were analysed using Logistic regression. Since the explanatory variables in the models were both metric and non-metric, and the character of the dependent variable was ordinal (ordered categorical), the list of statistical techniques was limited, and the choice of technique stood between two methods. Besides the logistic regression, discriminant analysis was an alternative because it also allows the dependent variable to be non-metric. Although this holds, the discriminant analysis technique requires that the explanatory variables are metric and that there are no large variations in the group sizes, since that would affect the estimation of the discriminant function and the classification of observations (Hair et al., 2014). The discriminant analysis technique would also fail to satisfy the group sizes assumption (Table 1). Regarding these two complications, the choice of statistical method favored the logistic regression. The goal with logistic regression was to predict the probability of an event occurring (in this study the event of having higher disease incidence) from the impact of the explanatory variables (Equation 1). The outcome was interpreted in terms of odds, where an odds is defined as the ratio of the probability of two outcomes of events.

Odds of having higher disease incidence $=$

$e^{\wedge}\left(\beta_{0}+\beta_{1}\right.$ age $+\beta_{2}$ pspecies $+\beta_{3}$ layout $+\beta_{4}$ weed +

$\beta_{5}$ variety $+\beta_{6}$ prune $+\beta_{7}$ climbing $+\beta_{8}$ sura + $\beta_{9}$ root $+\beta_{10}$ soil $+\beta_{11}$ intercroping) $\ldots$ Equation 1

Assumptions. For the analysis to be trustworthy, there are criteria that needed to be fulfilled, such as sample size, both overall and on a group-bygroup level, and if there was presence of multicollinearity between the explanatory variables. Recommendations state that at least 400 observations (Hair et al., 2014) are suitable for a reliable study. The sample for this investigation contained 533 different farm observations. Regarding the sample size per group of the dependent variable, the recommendation is to have at least 10 observations times the number of explanatory variables in each of the groups of the dependent variable (Hair et al., 2014). For the present study, that would mean to have at least $10 \times 15$ (explanatory variables levels, excluding the reference group) observations in each group of disease incidence level (data not shown) for model 1 (Equation 1), which does not hold (Table 1). Therefore, the second and third Equations were estimated containing only the significant variables from the first model. A single model, including all the five significant explanatory variables from Model 1 (Equation 1), would fail to satisfy the group-by-group assumption, that is why two separate models were developed (Equations 2 and 3).

Odds of having higher disease incidence $=$ $e^{\wedge}\left(\beta_{0}+\beta_{1}\right.$ age $+\beta_{2}$ pspecies $+\beta_{3}$ variety $+\beta_{4}$ root Equation 2

Odds of having higher disease incidence $=$

TABLE 1. Distribution of significant explanatory variables by CLYD disease incidence

\begin{tabular}{lcccc}
\hline Explanatory variables with significant effect & \multicolumn{3}{c}{ Disease incidence level (\%) } & Total \\
\cline { 2 - 4 } & $0-5$ & $>5-40$ & $>40$ & \\
\hline Farm age (years) & 283 & 183 & 63 & 529 \\
Other palm species & 280 & 179 & 63 & 522 \\
Coconut variety & 285 & 180 & 64 & 529 \\
Intercropping & 285 & 184 & 64 & 533 \\
Rootcut & 277 & 180 & 63 & 520 \\
\hline
\end{tabular}


$e^{\wedge}\left(\beta_{0}+\beta_{1}\right.$ age $+\beta_{2}$ pspecies $+\beta_{3}$ variety $+\beta_{4}$ intercropping) Equation 3

For the last two models (Equations 2 and 3), the recommended sample size per group of the dependent variable should at least be $10 \times 6$ (explanatory variables levels, excluding the reference group) $=60$ observations in each group of disease incidence level, which does hold (Table 1). Together, this information states that the assumption for the group sizes was satisfied.

The last thing to consider was multicollinearity between the explanatory variables in the model (Jaccard, 2001), where multicollinearity referred to the correlation between two or more variables. Spearman's Correlation Measure was used to investigate the pairwise correlations between numerical and ordinal variables in this study. Planting layout, coconut variety and soil types were not included in the correlation analysis, since they were strictly categorical variables.

Table 2 shows that there were no strong correlations between the independent variables, where a value higher than 0.70 can indicate a problem (Jaccard, 2001). Another way to check for multicollinearity was to look at the tolerance value (Equation 4). Tolerance is the amount of variability of a particular explanatory variable which is not explained by the other explanatory variables (Hair et al., 2014). The inverse of tolerance gives the variance inflation factor (VIF).

VIF $=\overline{\text { Tolerance }}$ Equation 4

The square root of VIF tells the degree to which the standard error of a certain explanatory variable has been increased due to multicollinearity. A VIF-value of 10 or higher (corresponding to a tolerance value of 0.1 or less) indicates that a variable is highly correlated to the others, and that there could be a problem with multicollinearity (Hair et al., 2014). Table 3, presents tolerance and VIF values for the explanatory variables. There was no sign of multicollinearity, hence the third recommendation was fulfilled. To summarise, all recommendations for a trustworthy study using logistic regression were, therefore, satisfied.

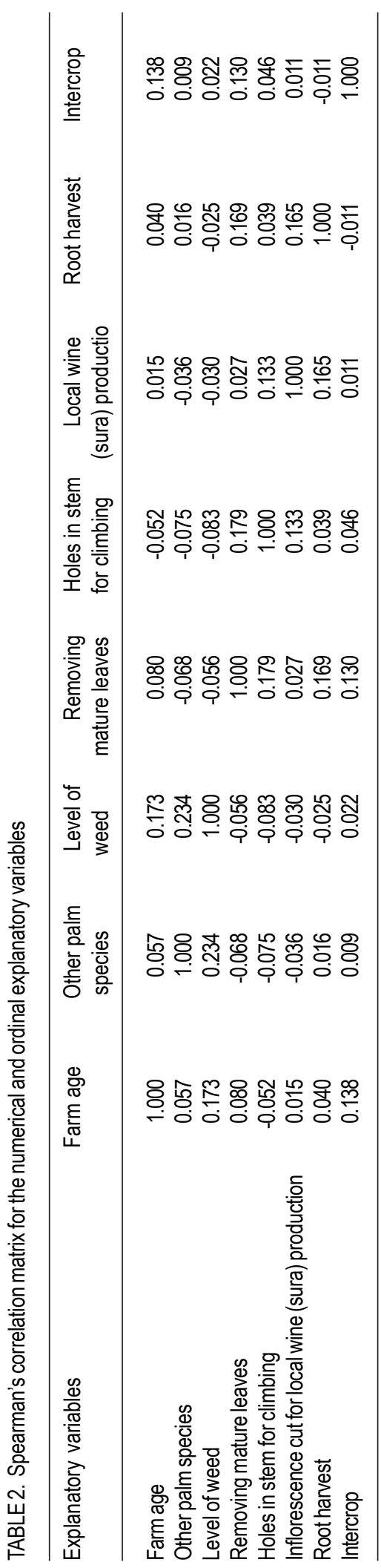


TABLE 3. Variance Inflation Factor (VIF) and tolerance values for the explanatory variables

\begin{tabular}{lcc}
\hline Explanatory variables & VIF values & Tolerance \\
\hline Farm age & 1.072 & 0.933 \\
Other palm species & 1.102 & 0.907 \\
Planting layout & 1.043 & 0.959 \\
Level of weed & 1.106 & 0.904 \\
Coconut variety & 1.013 & 0.987 \\
Removing mature leaves (prune) & 1.101 & 0.908 \\
Holes in stem for climbing & 1.087 & 0.920 \\
Inflorescence cut for local wine ("sura") production & 1.051 & 0.951 \\
Root cut & 1.071 & 0.934 \\
Soil type & 1.093 & 0.915 \\
Intercropping & 1.040 & 0.961 \\
\hline
\end{tabular}

Furthermore, the estimation of the disease incidence was based on symptomatic plants, and did not take into account the latent infection which may increase the model probability. It is also important to note how challenging it is to conduct field trials for CLYD related issues, for which the insect vector is yet unknown. Hence, we made assessment in non-experimental fields that have been affected by the disease.

\section{RESULTS}

The results from the constructed models are presented in Tables 4 - 5. Even though Model 1 did not satisfy the group-by-group size assumptions, overall the three models are concordant on the significant variables and Odds ratio estimates of the explanatory variables. Since the tree models explained the same thing, the results could be presented using any of them, but for consistency the results presentation was mainly based on models 2 and 3 since they satisfied all recommendations for trustworthy analyses.

Logistic regression analysis of models 2 and 3 indicated that five out of 11 explanatory variables had a significant $(\mathrm{P}<0.05)$ effect on the odds of CLYD incidence (Table 5). The variables with significant effects on the odds of a higher disease incidence were farm age (0-10 and more than 40 years old, compared to the reference category 10-40 years of age), presence of other palm species on the coconut farm, type of coconut variety grown (dwarf and hybrid varieties, compared to reference tall variety), root cut practices, and intercropping (Table 5).

Coconut farms of 10 or less years old had about three times (odds ratio $=2.727$ ) high odds of having higher disease incidence compared to the reference (10-40 years old); while coconut farms more than 40 years old had almost $10 \%$ lower odds (odds ratio $=0.926$ ) of having high disease incidence than the reference category. Moreover, the distribution within the variable farm age showed that approximately $45 \%$ of the farms were more than 40 years old, while only $5 \%$ were 0-10 years old (data not shown).

Moreover, coconut farms that had other palm species in the farm had almost two times (odds ratio $=1.691$ ) higher odds of having higher disease incidence level compared to farms without other palm species. From the overall sample, about $17 \%$ had other palm species on the farms. The other palm species commonly found on the coconut farms were the African oil palm (Elaeis guineensis), African fan palm (Borassus aethiopum), Senegal date palm (Phoenix reclinata) and Lala palm (Hyphaene coriacea) (data not shown).

Coconut farms planted with the dwarf variety had around $40 \%$ (odds ratio $=1.433$ ) higher odds of having higher disease incidence compared to farms with the tall variety; whereas coconut farms with the hybrid variety had around $60 \%$ lower odds of having higher disease incidence compared to farms with the tall variety (odds ratio $=0.385)$. The main variety grown in the study site was the tall variety (78\%), followed by the dwarf 
TABLE 4. Analysis of maximum likelihood and odds ratio estimates of Model 1

\begin{tabular}{|c|c|c|c|c|c|}
\hline Explanatory variables & & Degree of freedom & $\begin{array}{l}\text { Wald Chi-square } \\
\quad(P \text { value })\end{array}$ & $\begin{array}{l}\text { Odds Ratio } \\
\text { Estimates }\end{array}$ & $\begin{array}{l}\text { Confidence } \\
\text { intervals }\end{array}$ \\
\hline \multirow{2}{*}{ Farm age (years) } & $0-10$ against $>10-40$ & 1 & $6.518(0.011)$ & 2.761 & $1.189-6.41$ \\
\hline & $>40$ against $>10-40$ & 1 & $6.005(0.014)$ & 0.872 & $0.599-1.268$ \\
\hline Other palm species & & 1 & $5.499(0.019)$ & 1.792 & $1.101-2.919$ \\
\hline Planting layout & Zig-zag against in line & 1 & $0.658(0.417)$ & 1.285 & $0.701-2.354$ \\
\hline \multirow[t]{2}{*}{ Level of weed } & grasses against clean & 1 & $0.040(0.843)$ & 0.999 & $0.683-1.462$ \\
\hline & bushes against clean & 1 & $0.064(0.800)$ & 0.916 & $0.449-1.872$ \\
\hline \multirow[t]{2}{*}{ Coconut variety } & dwarfagainst tall & 1 & $6.175(\mathbf{0 . 0 1 3})$ & 1.414 & $0.876-2.282$ \\
\hline & Hybrid against tall & 1 & $5.162(0.023)$ & 0.421 & $0.173-1.027$ \\
\hline Removing mature leaves (prune) & & 1 & $0.211(0.646)$ & 0.917 & $0.633-1.328$ \\
\hline Holes in stem for climbing & & 1 & $0.587(0.444)$ & 0.828 & $0.51-1.343$ \\
\hline Inflorescence cut for local wine ("sura") production & & 1 & $3.029(0.082)$ & 2.037 & $0.914-4.537$ \\
\hline Root cut & & 1 & $6.660(0.010)$ & 2.777 & $1.278-6.032$ \\
\hline \multirow[t]{2}{*}{ Soil type } & Sand against between sand and soft clay & 1 & $0.117(0.733)$ & 0.743 & $0.203-2.713$ \\
\hline & soft clay against between sand and soft clay & 1 & $0.313(0.576)$ & 0.704 & $0.192-2.588$ \\
\hline Intercropping & & 1 & $8.779(0.003)$ & 1.842 & $1.23-2.759$ \\
\hline \multicolumn{6}{|l|}{ Goodness of fit statistics } \\
\hline Somers' D & & & 0.268 & & \\
\hline Gamma & & & 0.273 & & \\
\hline Tau-a & & & 0.156 & & \\
\hline $\mathrm{C}$ & & & 0.634 & & \\
\hline Likelihood ratio (Odds) & & & 0.541 & & \\
\hline
\end{tabular}


TABLE 5. Analysis of maximum likelihood and odds ratio estimates for Models 2 and 3

\begin{tabular}{|c|c|c|c|c|c|c|c|}
\hline \multirow[t]{2}{*}{ Explanatory variables } & & \multicolumn{3}{|c|}{ Model 2} & \multicolumn{3}{|c|}{ Model 3} \\
\hline & & $\begin{array}{l}\text { Wald Chi-square } \\
(P \text { value })\end{array}$ & $\begin{array}{l}\text { Odds ratio } \\
\text { estimates }\end{array}$ & $\begin{array}{c}\text { Confidence } \\
\text { intervals }\end{array}$ & $\begin{array}{l}\text { Wald Chi-square } \\
\quad(P \text { value })\end{array}$ & $\begin{array}{r}\text { Odds ratio } \\
\text { estimates }\end{array}$ & $\begin{array}{l}\text { Confidence } \\
\text { intervals }\end{array}$ \\
\hline \multirow[t]{2}{*}{ Farm age (years) } & $0-10$ versus $>10-40$ & $6.406(0.011)$ & 2.727 & $1.199-6.202$ & $5.371(0.021)$ & 2.416 & $1.080-5.404$ \\
\hline & $>40$ versus $>10-40$ & $5.269(0.022)$ & 0.926 & $0.643-1.332$ & $4.826(0.028)$ & 0.899 & $0.625-1.293$ \\
\hline Other palm species & & $4.590(0.032)$ & 1.641 & $1.043-2.583$ & $5.357(0.021)$ & 1.691 & $1.084-2.638$ \\
\hline \multirow[t]{2}{*}{ Coconut variety } & dwarf versus tall & $5.886(0.015)$ & 1.317 & $0.824-2.107$ & $7.357(0.007)$ & 1.433 & $0.902-2.279$ \\
\hline & Hybrid versus tall & $5.772(0.016)$ & 0.383 & $0.157-0.933$ & $6.215(0.013)$ & 0.385 & $0.159-0.935$ \\
\hline Root cut & & $7.401(0.007)$ & 2.805 & $1.334-5.896$ & & & \\
\hline Intercropping & & & & & $9.111(0.003)$ & 1.819 & $1.234-2.684$ \\
\hline \multicolumn{8}{|c|}{ Goodness of fit statistics } \\
\hline Somers' D & & 0.212 & & & 0.216 & & \\
\hline Gamma & & 0.257 & & & 0.245 & & \\
\hline Tau-a & & 0.123 & & & 0.125 & & \\
\hline C & & 0.606 & & & 0.608 & & \\
\hline Likelihood ratio (Odds) & & 0.7561 & & & 0.6231 & & \\
\hline
\end{tabular}


variety (16\%), and lastly the hybrid variety (6\%). These varieties could be further discriminated based on phenotype ranging from green, red, brown to yellow (data not shown).

Coconut farms where farmers cut roots for other purposes had three times higher odds of having higher disease incidence levels compared to farms that did not cut the roots (odds ratio = $2.805)$. The root cutting practice was not common in the study area, only $6 \%$ of the farmers reported this activity.

Coconut farms with some kind of intercropping had almost two times higher odds of having higher disease incidence levels compared to farms without intercropping (odds ratio $=1.819$ ). The proportion of farmers managing the farms using intercropping was $26 \%$. The crops most commonly intercropped with coconut were grain cereals, grain legumes and root tuber (data not shown).

Goodness of fit of the models. The models were concordant to detect variables with significant effect for increasing disease incidence. However it is important to show how good the predicted results of the models were. Table 5 show that both the measures Gamma and Somers' D (Goktas and Isci, 2011) had values above 0.20 , indicating that the models prediction values of the dependent variable were reliable. A value of 0 of these measures would indicate a random assignment of predicted values; while value of 1 would indicate perfect prediction; and -1 the opposite. Furthermore, Tau-C (Goktas and Isci, 2011) had a value above 0.5 , which is in line with the result from Gamma and Somers' D predictions. A Tau-C value of 0.5 indicates that the model randomly assigns the predicted values, and with a value of 1 all predicted values are correctly assigned. Moreover, the likelihood ratio estimates for the three models (Tables 4-5) are in line with the hypothesis of proportional odds which means that the effect of any higher level of CLYD incidence is of the same size. In summary, the predicted results of the models were trustworthy.

\section{DISCUSSION}

The observation that coconut farms aged 10 years or less were more vulnerable to the disease, while coconut farms with more than 40 years old had succumbed less to the disease (Table 5), may be due to increased tolerance of the disease in older plants. For example, in Ghana Vanuatu Tall (VTT) mature palms that initially tested positive for phytoplasmas, had not yet developed symptoms after six years. Incubation periods of more than 28 months were recorded in mature Malayan Yellow Dwarf x VTT hybrids (Nipah, 2000). Harris and Maramorosch (2013) reported an incubation period of LY phytoplasmas in young coconut palms of 3-11 months. This confirms that mature coconut palms are more tolerant than young ones. Furthermore, younger coconut palms are preferred hosts for the adult of the coconut beetle Oryctes monoceros (Allou, et al., 2006; Allou, et al., 2012), a major coconut pest in Mozambique, which may weaken the palm. Damage is generally caused by adult beetles making feeding galleries in the apical section of young palms, but also of mature palms when beetle populations are large (Allou, et al., 2006).

The detected significant effect of the presence of other palm species in coconut farms for higher odds of CLYD incidence (Table 5), was not surprising because more than 30 palm species have been shown to be susceptible to lethal phytoplasmas (Howard, 1992). Nearly all other palm species commonly found in the coconut farms in Mozambique, such as African oil palm (E. guineensis), African fan palm (Borassus aethiopum), Senegal date palm (Phoenix reclinata) and Lala palm (Hyphaene coriacea) have been associated with LY Phytoplasma elsewhere (Howard, 1992). Members of subgroup $16 \mathrm{SrIV}$ of the LY phytoplasmas, infecting coconut, have also been found to cause LY-like symptoms in Silver date palm (Phoenix sylvestris), edible Date palm (Phoenix dactylifera), Queen palm (Syagrus romanozoffiana), Mexican fan palm (Washingtonia robusta) Sabal palm (Sabal palmetto), Bismarck palm (Bismarckia nobilis), Royal palm (Roystonea regia), African oil palm (E. guineensis) and Foxtail palm (Wodyetia bifurcata) (Brown et al., 2008; Nejat et al., 2009;).

Accordingly, the two naturalised palm species, African Fan Palm (Borassus aethiopum) and Oil Palm (Elaeis guineensis), were recently recorded as alternative hosts of CLYD in 
Mozambique (Bila et al., 2015). It is, therefore, sensible that the presence of other palm species increases the odds for higher CLYD incidence, since the other palm species can act as reservoirs of inoculum for the coconut palms.

Coconut farms planted with the dwarf variety had around $40 \%$ higher odds of having higher disease incidence, compared to farms with the tall variety (Table 5); whereas coconut farms with the hybrid variety had around $60 \%$ lower odds of having higher disease incidence compared to the tall variety. This finding suggests that tall varieties are relatively more tolerant to phytoplasma associated with CLYD compared to the dwarf variety. This result is in line with current CLYD management strategy in Mozambique, which consists of removal (cut and burn) of symptomatic coconut trees, and replacement with the Mozambique giant green tall tolerant variety. Eden-Green (2006) reported that the Mozambique Tall (MZT) variety can survive prolonged exposure to the disease. Based on our results, the Mozambique giant green tall variety can still be considered tolerant to CLYD.

Coconut farms where farmers cut roots had three times higher odds of having higher disease incidence (Table 5). LY disease of palms, are also referred to as "lethal decline", "root wilt" and white tip die-back (Mehdi et al., 2012). Oropeza et al. (2011) investigated the phytoplasmas distribution in different coconut parts and found a very high level of LY phytoplasmas DNA in stem, young leaves, inflorescences, stem apex and root apex. However, low levels were found in the intermediate leaves and roots without apex. This suggests that roots are important parts in the epidemiology of LY disease.

The combined effect of root cut and wilting because of the LY phytoplasma infection, is likely to affect water and nutrients acquisition by the plants. Moreover, the combined injury caused by root cutting and phytoplasma may be entry points for other pests, and may weaken the plant defence due to co-infection (Gitau et al., 2009). Several researchers (Garnier et al., 2001; Weintraub and Beanland, 2006; Bertaccini, 2007; Nejat and Vadamalai, 2010) have reported the dependence on phloem-sucking insect vectors for phytoplasma transmission. Gitau et al. (2009) also reported examples of pathogen transmission vectored by non-sucking insects feeding at plant wounds or open cuts.

Coconut farms with some kind of intercropping had two times higher odds of having higher disease incidence levels compared to farms with monocropping (Table 5). Intercropping has been widely recommended as an IPM strategy for many plant diseases, including palm (Gitau et al., 2009). The results of this study contradict this suggestion, since intercropping increased the odds of high disease incidence. In line with this, Oleke et al. (2012) found that intercropping coconut with cassava, maize, cashew nut, sorghum and/or pineapples served as alternative crops used by farmers to cope with declining coconut production, caused by coconut mite and lethal yellowing disease in Tanzania. However, the practices were not promising as part of the disease management strategy. In Ghana, Andoh-Mensah and OfosuBudu (2012) also found that intercropping coconut with citrus did not lower CLYD incidence, but contributed to a substantial part of the fruit income as insurance against lethal yellowing disease.

In general, intercropping seems to be important in terms of income replacement for coping with declining coconut production due to CLYD, rather than controlling the disease. In our study, about $26 \%$ of the farmers in the study site intercropped coconut palm mostly with grain cereals, grain legumes and root tuber. It is also important to note that some of the crops used by the farmers for intercropping could also be hosts to yet unknown CLYD insect vectors in Mozambique. For example, in the Caribbean palm plantations, maintaining grass that impedes development of LY phytoplasmas vector, $H$. crudus larvae, has been a successful practice (Howard, 1990). May be, in Mozambique, better CLYD management could be achieved by intercropping coconut with similar height plants, which are likely to affect the sensory ability and movement of the insect from one palm to another. The effect of intercropping is still unclear and requires additional research to be explained.

Other tested variables did not show effect on CLYD incidence (Table 4). Therefore, based on this study, planting layout, weeding, the removal of mature leaves, cutting steps in the trunk, 
cutting the inflorescence for local wine production or soil type had no affect on CLYD incidence. However, in Caribbean and Malaysia, LY phytoplasmas have been detected in grass species such as Emelia forsbegii, Synedrella nodiflora and Bermuda grass (Cynodon dactylon) (Brown et al., 2008; Nejat et al., 2009); hence the importance of weeding cannot be neglected. Likewise, the cutting of newly emerged inflorescences for local wine production did not show any significant effect on the disease incidence, even though inflorescences were among the palm parts with higher level of lethal yellowing-type phytoplasma DNA (Oropeza et al., 2011).

\section{ACKNOWLEDGEMENT}

This work was co-funded by the Swedish International Development Agency (SIDA) and the Millennium Challenge Account in Mozambique. The authors are grateful to Verde Azul Company staff and invited consultants, especially to the Director Eng. Kemal Vaz, for the assistance provided to design and conduct the survey.

\section{REFERENCES}

Agrios, G.N. 2005. Plant Pathology. ElsevierAcademic Press, San Diego, CA, USA. 922pp.

Allou, K., Morin, J.P., Kouassi, P., N'Klo, F. H. and Rochat, D. 2006. Oryctes monoceros trapping with synthetic pheromone and palm material in ivory coast. Journal of Chemical Ecology 32(8): 1743-1754.

Allou, K., Issali, A.E., Lekadou, T., Konan, K.J.L., Zakra, N., Kouassi, K.P., Bourdeix, R., Morin, J.P. and Saraka, Y.D.M. 2012. Comparative synergetic effect of coconut palm (Cocos nucifera $\mathrm{L}$.) slices and bunches residue of oil palm (Elaeis guineensis JACQ.) associated with two kinds of pheromone traps on Oryctes monoceros OLIVIER trapping in Côte d'Ivoire. International Journal of Emerging Technology and Advanced Engineering 2(6):1-6.

Andoh-Mensah, E. and Ofosu-Budu, G.K. 2012. Evaluation of coconut citrus intercropping systems in context of coconut lethal yellowing in Ghana. African Journal of Food, Nutrition and Development 12(7): 6945-6962.

Bertaccini, A. 2007. Phytoplasmas: Diversity, taxonomy and epidemiology. Frontiers in Bioscience 12:673-689.

Bila, J., Mondjana, A., Samils, B. and Högberg, N. 2014. High diversity, expanding populations and purifying selection in phytoplasmas causing coconut lethal yellowing in Mozambique. Plant Pathology 64:597-604.

Bila, J., Högberg, N., Mondjana, A. and Samils, B. 2015. African fan palm (Borassus aethiopum) and oil palm (Elaeis guineensis) are alternate hosts of coconut lethal yellowing phytoplasma in Mozambique. African Journal of Biotechnology 14(52): 3359-3367.

Broshat, T.K., Harrison, N.A. and Donselman, H. 2002. Lethal yellowing cast doubt on coconut cultivar resistance. PALMS 46(4):185-189.

Brown, S. E., Been, B. O. and McLaughlin, W. A. 2006. Detection and variability of the lethal yellowing group (16Sr IV) phytoplasmas in the Cedusa sp. (Hemiptera: Auchenorrhyncha: Derbidae) in Jamaica. Annals of Applied Biology 149(1): 53-62.

Brown, S., Been, B.O. and McLaughlin, W.A. 2008. First report of the presence of the lethal yellowing group (16Sr IV) of phytoplasmas in the weeds Emelia fosbergii and Synedrella nodiflora in Jamaica. Plant Pathology 57: 770.

Caudwell, R.W. 2000. The successful development and implementation of an integrated pest management system for oil palm in Papua New Guinea. Integrated Pest Management Reviews 5: 297-301.

Eden-Green, S.J. 2006. An assessment of coconut Lethal Yellowing-type Disease (LYD) in Mozambique. Consultant's report by EG Consulting, UK. 24pp.

Eziashi, E. and Omamor, I. 2010. Lethal yellowing disease of the coconut palms (Cocos nucifera L.): An overview of the crises. African Journal of Biotechnology 9: 9122-9127.

Garnier, M., Foissac, X., Gaurivaud, P., Laigret, F., Renaudin, J., Saillard, C. and Bové, J.P. 2001. Mycoplasmas, plants, insect vectors: A matrimonial triangle. Comptes Rendus de l'Academie des Sciences 324:923-928. 
Gitau, C.W., Gurr, G.M., Dewhurst, C.F., Fletcher, M.J. and Mitchell, A. 2009. Insect pests and insect-vectored diseases of palms. Australian Journal of Entomology 48: 328-342.

Goktas, A. and Isci, O. 2011. A comparison of the most commonly used measures of association for doubly ordered square contingency tables via simulation. Metodoloski zvezki 8(1): 17 37.

Hair, J.F., Black, W.C., Babin, B.J. and Anderson, R.E. 2014. Multivariate data analysis. Harlow: Pearson Education Limited, USA. 734pp.

Harris, K.F. and Maramorosch, K. 2013. Vectors of Plant Pathogens, Academic Press, USA. 482pp.

Howard, F.W. 1992. Lethal Yellowing Susceptibility of Date Palms in Florida. Principes 36(4): 217-22.

Howard, F.W. 1990. Evaluation of grasses for cultural control of Myndus crudus, a vector of lethal yellowing of palms. Entomologia Experimentalis et Applicata 56: 131-137.

Howard, F.W. and Oropeza, C. 1998. Organic mulch as a factor in the nymphal habitat of Myndus crudus (Hemiptera: Auchennorhyncha: Cixiidae). The Florida Entomologist 81: 92-97.

Jaccard, J. 2001. Interaction effects in logistic regression: Quantitative Applications in the Social Sciences. Sage Publications Ltd. London, UK.

Lee, I.M., Davis, R.E. and Gundersen-Rindal, D.E. 2000. Phytoplasma: Phytopathogenic mollicutes. Annual Review of Microbiology 54: $221-255$
Mehdi, A., Baranwal, V.K., Kochu, Babu, M. and Praveena D. 2012. Sequence Analysis of 16S rRNA and secA genes confirms the association of 16SrI-B subgroup phytoplasma with oil palm (Elaeis guineensis Jacq.) Stunting Disease in India. Jounal of Phytopathology 160:6-12.

Nejat, N., Sijam, K., Abdullah, S.N.A., Vadamalai, G. and Dickinson, M.J. 2009. Phytoplasmas associated with disease of coconut in Malaysia: Phylogenetic groups and host plant species. Plant Pathology 58:1152-1160.

Nejat, N. and Vadamalai, G. 2010. Phytoplasmas detection in coconut palms and other tropical crops. Plant Pathology Journal 9(3): 112-121

Nipah, J.O. 2000. Some characteristics of the Sri Lanka Green Dwarf (SGD): A variety resistant to the Cape Saint Paul wilt disease of coconut. Journal of the Ghana Science Association 2:88-93.

Oleke, J.M., Isinika, A., Manyong, V., Hanna, R. and Sabelis, M. 2012. Farmers' perception of coconut mite damage and crop diversification alternatives in the coastal belt of Tanzania. International journal of Acarology 38(6): 471479.

Oropeza, C., Cordova, I., Chumba, A., Narvaez, M., Saenz, L., Ashburner, R. and Harrison, N. 2011. Phytoplasma distribution in coconut palms affected by lethal yellowing disease. Annals of Applied Biology 159: 109-117.

Weintraub, P. G. and Beanland, L. 2006. Insect Vectors of Phytoplasmas. Annual Review of Entomology 51(1): 91-111. 